\title{
The new foraminiferal genus Ammogloborotaloides n. gen. and subfamily Ammogloborotaloidinae n. subfam. from the Neogene of Venezuela: an example of isomorphism between agglutinated and planktonic Foraminifera
}

\author{
MICHAEL A. KAMINSKI ${ }^{1, *}$ \& JIME CONTRERAS ${ }^{2}$ \\ ${ }^{1}$ Earth Sciences Department, King Fahd University of Petroleum \& Minerals Dhahran, 31261, Saudi Arabia \\ ${ }^{2}$ PDVSA Geological Laboratory 'La Concepcion', Campo OLeary, Edificio Laboratorio y Nucleoteca Oficina No. 5, La Concepcion, \\ Zulia State, Venezuela \\ *Corresponding author (e-mail: kaminski@kfupm.edu.sa)
}

\begin{abstract}
We report the occurrence of two new species of the new agglutinated foraminiferal genus Ammogloborotaloides in the Miocene of western Venezuela. These two taxa have been assigned informal names and have been known to the petroleum industry in Venezuela for many years, but have never been described. A. truncatulinoidiformis n. sp. is the type species and the second species, $A$. sp. 16, is left in open nomenclature. The two species of Ammogloborotaloides are strongly isomorphic with the planktonic foraminiferal species Globorotalia truncatulinoides and Globorotalia crassaformis, and illustrate the possible evolutionary connections between agglutinated benthics and the planktonic foraminifera. J. Micropalaeontol. 30(1): 11-16, May 2011.
\end{abstract}

KEYWORDS: foraminifera, Ammogloborotaloides $n$. gen., Venezuela, Miocene

\section{INTRODUCTION}

As part of a programme to revise the taxonomy of benthic foraminifera in the collections of the Venezuelan State Petroleum Company (PDVSA), we examined numerous numbered slides labelled 'Trochammina' in the type collections housed in the Geological Laboratory in La Conception, Venezuela. Among the numerous unnamed species of trochamminids present in the collections, we discovered striking examples of species that we first provisionally assigned to the genus Ammogloborotalia Zheng, 2001. However, upon closer examination of the apertural characteristics, the Neogene taxa were found to differ from Cretaceous and Recent Ammogloborotalia, which necessitated the establishment of a new genus. These taxa from the Miocene of the Falcon Basin and from Lake Maracaibo are strongly isomorphic with late Neogene species of Globorotalia. The purpose of this paper is to provide descriptions of these new taxa, and point out their strong isomorphism with well-known modern species of Globorotalia.

\section{MATERIAL AND METHODS}

The 'Shell Collection' housed in the Geological Laboratory in La Concepcion consists of three trays of trochamminids from western Venezuela, with the species slides simply labelled Trochammina-1 to Trochammina-21. The collection of foraminiferal type slides dates from the 1950s, and the numbered species designations have been in general use in the Venezuelan petroleum industry for many years. We additionally examined well samples from the lower Miocene La Rosa Formation of the Lagomar petroleum field in Lake Maracaibo to recover additional specimens (Fig. 1).

Specimens were photographed wet and dry using a Zeiss SV12 binocular microscope with a Canon digital camera, and then photographed using the FEI-600 environmental SEM at PDVSA in Puerto La Cruz. The primary types were deposited at the P.J Bermúdez Micropaleontological Center at PSVSAINTEVEP (el Instituto Tecnológico Venezuelano del Petróleo) in Los Teques, near Caracas, Venezuela. These collections are accessible to the public upon appointment (www.pdvsa.com/ lexico/centro/micropaleontologia.htm).

\section{SYSTEMATIC PALAEONTOLOGY}

Family Trochamminidae Schwager, 1877 Subfamily Ammogloborotaloidinae n. subfam.

Description. Text free, coiled in a low trochospire, chambers increasing in size slowly, with acute or keeled periphery. Aperture extraumbilical, areal, in the middle of the apertural face.

Remarks. Differs from the Vialovinae in having chambers that increase in size slowly, lacking a tendency to uncoil, and in the acute or keeled periphery.

Genus Ammogloborotaloides Kaminski \& Contreras n. gen.

Type species. Ammogloborotaloides truncatulinoidiformis Kaminski \& Contreras n. gen., n. sp.

Description. Test strongly umbilico-convex with circular outline in axial view, and an acute to keeled peripheral margin. Spiral side flat or elevated slightly in the centre, with a depressed coil suture and an elevated peripheral rim or keel. All chambers are visible on the spiral side. Chambers on the spiral side are elongated in the direction of coiling and have radial sutures. The umbilical side is strongly convex, with triangular chambers in umbilical view, depressed sutures and a closed umbilicus. The apertural face is flat, and the aperture is a small circular areal opening in the middle of the apertural face, midway between the umbilicus and the periphery, surrounded by an elevated rim or neck. The wall is comprised of medium to fine quartz grains, with a smooth surface, and is silicified.

Remarks. The genus Ammogloborotalia Zheng, 2001 (in Zheng $\& \mathrm{Fu}, 2001$ ) is strongly isomorphic to our new genus, but differs 


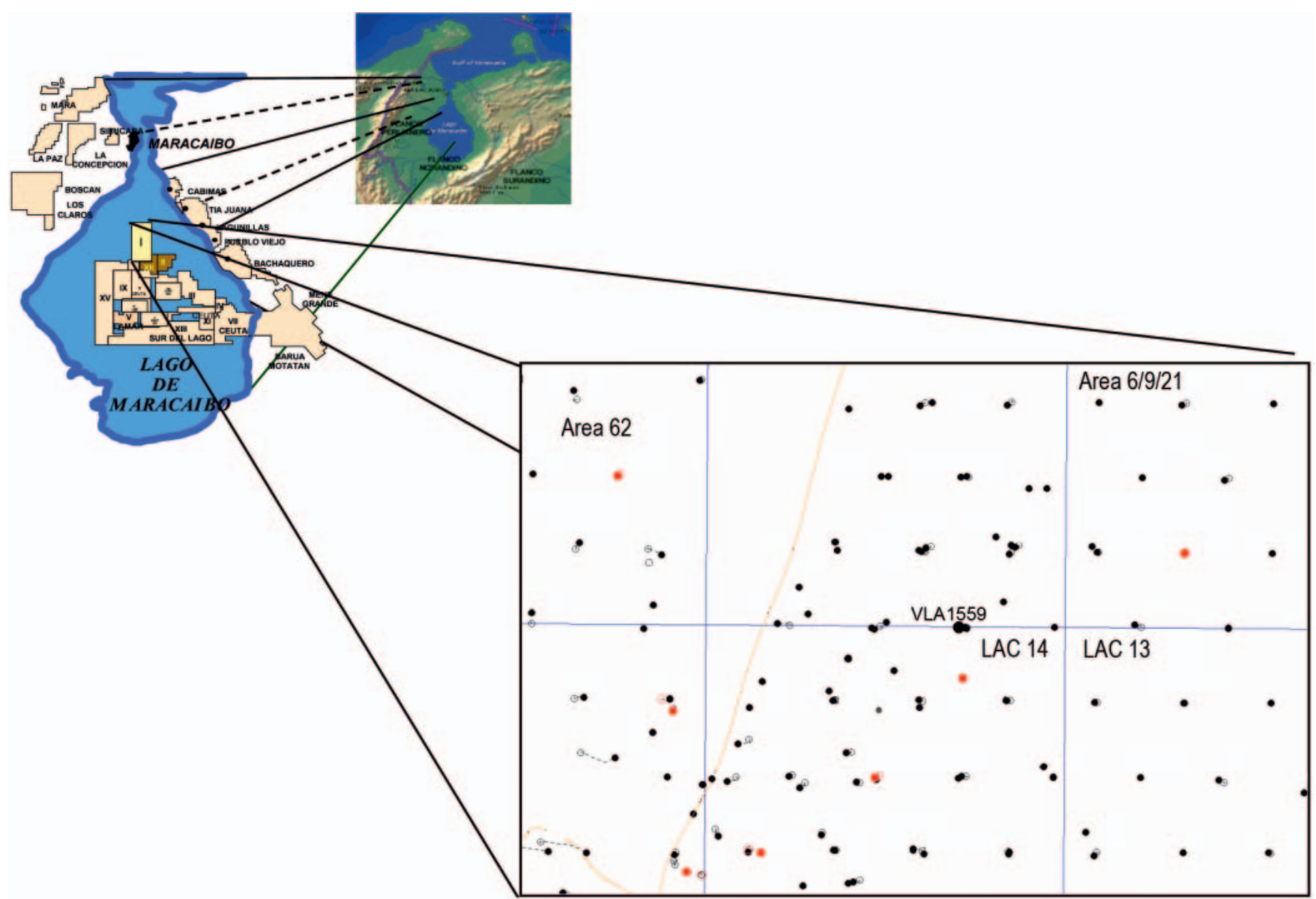

Fig. 1. Location of Block 1, Lake Maracaibo, showing well VLA-1559ST. Dots show locations of other wells.

in possessing an interiomarginal aperture. Ammogloborotalia was first described from surface sediments collected from a $2100 \mathrm{~m}$ deep station in the East China Sea. The type species, Ammogloborotalia stellaris Zheng, 2001 is a strongly umbilicoconvex form with triangular chambers and a sharp periphery, and externally resembles a 4-chambered species of Globorotalia. Other species of Ammogloborotalia are also present in Cretaceous deep-sea sediments recovered from the Indian Ocean and the Carpathians (Kaminski et al., 2008).

\section{Ammogloborotaloides truncatulinoidiformis Kaminski \& Contreras n. gen., n. sp.}

(Pl. 1, figs 1-3; Pl. 2, fig. 1)

Derivation of name. From the strong external resemblance to the Pleistocene-Holocene planktonic foraminiferal species Globorotalia truncatulinoides (d'Orbigny).

Material. Sixteen specimens housed in the collections of PDVSA in La Conception and at INTEVEP in Los Teques, near Caracas. The paratype specimens were housed in two slides in the PDVSA (La Conception) type collection and were simply labelled 'Trochammina sp.'. The holotype is from well VLA-1559ST, Lagomar Oil Field, Lake Maracaibo and is deposited in the Centro de Micropaleontologia P.J Bermúdez at
PSVSA-INTEVEP in Los Teques, Venezuela in Slide 021045. The figured paratypes are from the PDVSA (La Concepcion) type collection slide 1324, and are now deposited at PSVSAINTEVEP in slide 021046.

Type locality. Well VLA-1559ST, Lagomar Oil Field, Lake Maracaibo.

Type level. La Rosa sand (informal member name) of the La Rosa Formation in well VLA-1559ST, at 5660-5670 feet.

Description. Test strongly umbilico-convex with circular and distinctly keeled peripheral margin in axial view. Spiral side flat, with a depressed coil suture and an elevated peripheral rim corresponding to the keel in the species Globorotalia truncatulinoides. All chambers are visible on the spiral side, which is comprised of $2 \frac{1}{2}$ whorls with five chambers in the final whorl. Chambers on the spiral side are elongated in the direction of coiling and have radial sutures that appear as dark bands. The final two chambers are imbricated. The umbilical side is strongly convex, with triangular chambers in umbilical view, and slightly depressed sutures and a closed umbilicus. The apertural face is flat and the aperture is a small areal opening in the middle of the apertural face, midway between the umbilicus and the periphery, surrounded by an elevated rim. The wall is comprised of medium to fine quartz grains with a terrazzo finish. 


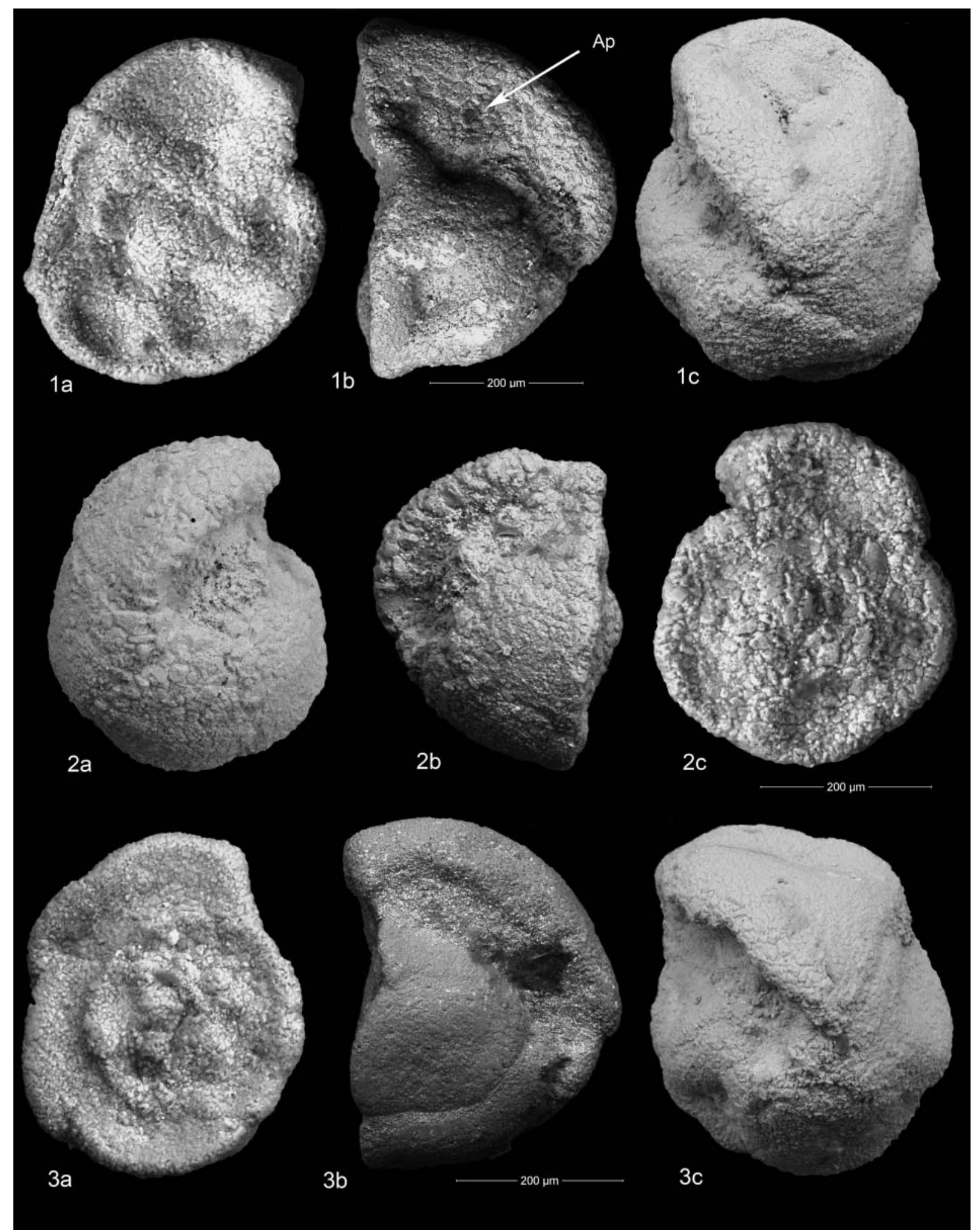

Explanation of Plate 1.

figs 1a-3c. Ammogloborotaloides truncatulinoidiformis Kaminski \& Contreras, n. gen., n. sp., Falcon Basin, paratypes. INTEVEP slide 021046, ex PDVSA (La Concepcion) Type Collection, slide 1324, Spiral, edge and ventral views. Arrow notes position of aperture. 


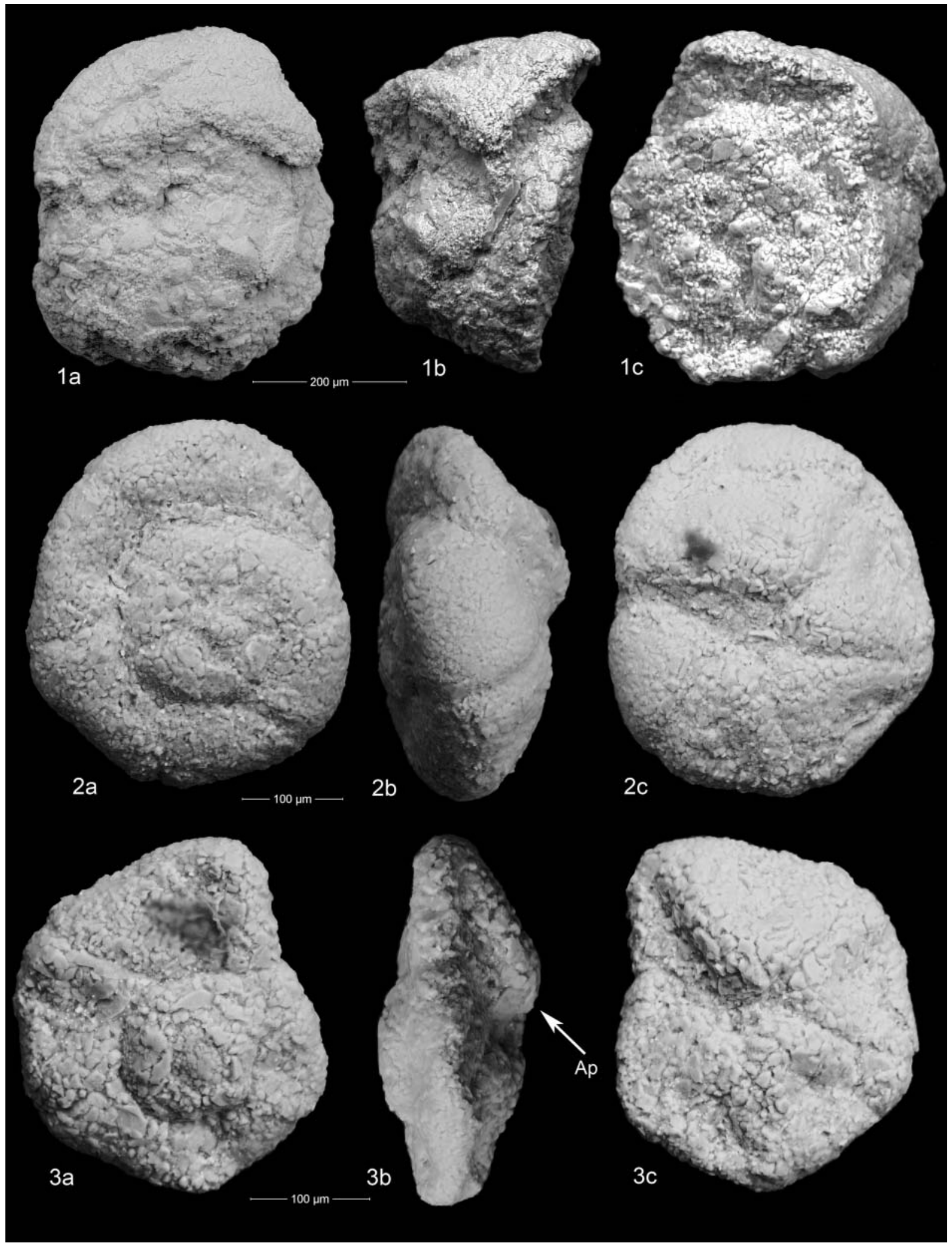

Explanation of Plate 2.

figs 1a-c. Ammogloborotaloides truncatulinoidiformis Kaminski \& Contreras, n. gen., n. sp., Miocene, well VLA-1559ST, Lagomar Oil Field, Lake Maracaibo. Holotype, slide 021045. figs 2a-3c. Ammogloborotaloides sp. 16. INTEVEP slide 021047, ex-Shell Venezuela type collection, PDVSA (La Concepcion). Arrow notes position of aperture. 
Dimensions. Holotype - maximum diameter measured on spiral side: $0.50 \mathrm{~mm}$; height of last chamber in apertural view: $0.35 \mathrm{~mm}$.

Remarks. With its strong keel, which is especially apparent when viewed in immersion, this species bears a striking resemblance to the modern planktonic species $G$. truncatulinoides. In lateral (apertural) view, the keel appears to continue from the basal margin along the leading top edge of the apertural face. The last chamber overlaps the umbilicus and, as a result, the umbilicus is closed. The aperture is a small circular opening in areal position, and surrounded by a thin, slightly elevated rim of agglutinated grains.

The species is known thus far from two localities in western Venezuela: specimens in the PDVSA type collection are from a Miocene outcrop sample from the Falcon Basin, but the exact locality is unknown. These specimens are very well preserved but, because we could not designate a type locality, they can serve only as secondary types. The holotype was recovered from a well in the Lagomar Field in Lake Maracaibo, and is derived from the La Rosa sand member, of early Miocene age. The La Rosa sand member contains a foraminiferal assemblage with Amphistegina chipolensis Cushman \& Ponton, as well as Haplophragmoides sp., Lenticulina spp., Elphidium spp. and small (juvenile) planktonics belonging to the genera Globigerinoides and Globigerinella. The depositional environment is regarded to be inner to middle neritic, and the La Rosa sand member itself is interpreted as representing a transgressive facies.

Ammogloborotaloides sp. 16 (industry name)

(Pl. 2, figs 2-3)

Synonymy. 'Trochammina sp. 16' (industry name from the Shell Venezuela type collection).

Material. Five specimens housed in the collections of PDVSA in La Conception, Venezuela; figured specimens are deposited in the Centro de Micropaleontologia P.J Bermúdez at PSVSAINTEVEP in Los Teques, Venezuela and are registered in slide 021047.

Description. Test umbilico-convex with circular to rhomboid outline and subacute to acute peripheral margin in axial view. Spiral side flat or elevated slightly in the centre, with a depressed coil suture, comprising $2 \frac{1}{2}$ whorls with five chambers in the final whorl. Chambers on the spiral side are elongated in the direction of coiling, with radial sutures. Umbilical side convex, with triangular chambers and radial, slightly depressed sutures, and a narrow open depressed umbilicus. The aperture is a small circular areal opening in the middle of the apertural face, midway between the umbilicus and the periphery, surrounded by a raised lip. Wall is comprised of medium to fine quartz grains with a roughened finish.

Remarks. Differs from Ammogloborotaloides truncatulinoidiformis $\mathrm{n}$. $\mathrm{sp}$. in lacking a distinct keel, in its less convex umbilical side and open circular umbilicus. The 'keel' is apparent only in compressed specimens, while well-preserved specimens clearly have a subacute periphery. Specimens from the Shell collection in La Concepcion are from surface outcrops in the Falcon
Basin. The exact locality of the Ammogloborotaloides-bearing sample is unknown and there is no reason to assume that both Ammogloborotaloides species are from the same locality. We, therefore, refrain from describing this species formally until a type locality can be identified. $A$. sp. 16 most closely resembles the planktonic foraminifer Globorotalia crassaformis (Galloway \& Wissler) in external morphology, although the latter usually has only four chambers in the final whorl and is slightly more convex on the ventral side.

\section{DISCUSSION}

The obvious and striking isomorphism between some Miocene species of trochamminids and Pliocene-Pleistocene globorotaliids is a topic that deserves further investigation. Additional examples of isomorphism between planktonic and agglutinated benthic genera are known from the Late Cretaceous, especially between the agglutinated genus Ammoanita and the planktonic genus Contusotruncana (see Kaminski \& Gradstein, 2005, p. 456). As early as 1945, Joseph Cushman pointed out that morphological trends can and do occur in parallel in different foraminiferal lineages. In our view, the similarities between trochamminids and some of the deeper-dwelling planktonic foraminifera are too close to ignore and suggest a possible link. In the modern ocean the cross-over between a benthic and planktonic habitat is not unknown: for example the genus Globorotalia has been observed to fall to the sea floor and behave as a benthic (Hilbrecht \& Thierstein, 1996). Similarly, studies of molecular biology have shown that some benthic foraminifera can adopt a planktonic life style, as in the case of the biserial morphospecies Bolivina variablis Williamson and Streptochilus globigerus (Schwager) (Darling \& Leckie, 2010), which are the same biological species. Because of the fundamental differences in the wall structure between planktonics and agglutinated foraminifera and their disjunct stratigraphic ranges, the idea of an evolutionary link between the new genus and Globorotalia truncatulinoides seems far-fetched. However, studies of small subunit ribosomal DNA do suggest a link between modern trochamminids and rotaliform benthic foraminifera (Pawłowski, 2000; Ertan et al., 2004). In the case of this extinct Neogene genus, the agglutinated isomorph is older than its planktonic equivalent. The fact that the genus Ammogloborotaloides is presumed extinct precludes the idea of testing similarity based on rDNA sequences, but external morphological similarities between them are undeniable.

\section{ACKNOWLEGEMENTS}

The revision of agglutinated foraminiferal genera is supported by a consortium of petroleum companies and micropaleontological consultancies (BP, Saudi Aramco, Shell, Total, PDVSA, RPS Energy, Fugro Robertson Ltd, Chevron, Petronas, Petrobras). The authors thank Franklin Morales for his help with the Environmental SEM at PDVSA in Puerto La Cruz, and Claudia Cetean (NHM, London), Bob Jones (NHM, London) and Steve Culver (East Carolina University) for reviewing the manuscript and offering helpful comments. This is contribution no. 94 of the Deep-Water Agglutinated Foraminiferal Project.

\section{Manuscript received 30 November 2010 Manuscript accepted 19 January 2011}

Scientific editing by Alan Lord 


\section{REFERENCES}

Cushman, J.A. 1945. Parallel evolution in the Foraminifera. American Journal of Science, 234A: 117-121.

Darling, K. \& Leckie, R.M. 2010. Bridging the Benthic/Planktic divide. In FORAMS 2010 Abstracts volume with program. Baylaydruk, Bonn, p. 74.

Ertan, K.T., Hemleben, V. \& Hemleben, C. 2004. Molecular evolution of some selected benthic foraminifera as inferred from sequences of the small subunit ribosomal DNA. Marine Micropaleontology, 53: 367-388.

Hilbrecht, H. \& Thierstein, H.R. 1996. Benthic behaviour of planktic foraminifera. Geology, 24: 200-202.
Kaminski, M.A. \& Gradstein, F.M. 2005. Cenozoic cosmopolitan deepwater agglutinated foraminifera. Grzybowski Foundation Special Publication, 10, 547pp.

Kaminski, M.A., Cetean, C.G., Henderson, A.S. \& Filipescu, S. 2008. On the Cretaceous occurrences of Ammogloborotalia Zheng, 2001. Studia Universitatis Babes-Bolyai, Geologia, 52(2): 67-71.

Pawłowski, J. 2000. Introduction to the molecular systematics of foraminifera. Micropaleontology, 46: 1-12.

Zheng, S. \& Fu, Z. 2001. Fauna Sinica, Phylum Granuloreticulosa, Class Foraminiferea, Agglutinated Foraminifera. Science Press, Beijing, 788 pp. +122 pls. 